\title{
IP-10 Mediates Selective Mononuclear Cell Accumulation and Activation in Response to Intrapulmonary Transgenic Expression and During Adenovirus-Induced Pulmonary Inflammation
}

\author{
XIANYING ZENG, THOMAS A. MOORE, MICHAEL W. NEWSTEAD, JANE C. DENG, \\ NICHOLAS W. LUKACS, and THEODORE J. STANDIFORD
}

\begin{abstract}
CXC chemokines that lack the glutamine-leucine-arginine (ELR) motif, including interferon (IFN)-inducible protein 10 (IP-10 or CXCL10), have been shown to mediate the generation of type 1 immune responses. In this study, we found that the intrapulmonary transient transgenic expression of murine IP-10 in mice using adenoviral gene transfer resulted in the early accumulation of neutrophils, natural killer (NK) cells, and NK $\mathrm{T}$ cells within the lung, followed by the delayed accumulation of $\mathrm{CD4}^{+} \mathrm{T}$ cells. Adenovirus-mediated transgenic expression of IP-10 also resulted in selective activation of mononuclear cells, including $\gamma \delta$-T cells and NK cells, as manifest by CD69 expression or induction of cell-associated IFN- $\gamma$. Importantly, the intratracheal (i.t.) administration of a control human type 5 adenovirus also caused significant accumulation of NK, NK T, and $\mathrm{CD4}^{+} \mathrm{T}$ cells, which was maximal at 7 days post vector administration and was associated with the induction of IP-10. Neutralization of endogenous IP-10 in animals receiving control adenovirus resulted in decreases in the numbers of $\mathrm{NK}, \mathrm{CD}^{+}$, and $\mathrm{CD8}^{+} \mathrm{T}$ cells. These results indicate that IP-10 can direct the accumulation and activation of neutrophils and selected mononuclear cells to the lung and that adenovirusinduced IP-10 contributes to lung inflammatory cell recruitment/activation observed in response to adenoviral vectors used for gene therapy.
\end{abstract}

\section{INTRODUCTION}

$\mathbf{T}$ HE GENERATION OF INFLAmMation is dependent on establishment of chemotactic gradients that direct the migration of leukocytes. Chemokines are a large family of proteins that mediate the movement of diverse groups of inflammatory cells. ${ }^{(1)}$ The chemokine family consists of four subfamilies based on the positioning of $\mathrm{N}$-terminal cysteines within their amino acid structure and include $\mathrm{C}, \mathrm{CC}, \mathrm{CXC}$, and $\mathrm{CXC} 3$ subtypes. CXC chemokines the lack the ELR motif just proximal to the first $\mathrm{N}$-terminal cysteine are distinguished from ELRcontaining CXC chemokines not only structurally but also functionally. For instance, $\mathrm{ELR}^{-} \mathrm{CXC}$ chemokines, including interferon (IFN)-inducible protein 10 (IP-10 or CXCL10), monokine induced by IFN- $\gamma$ (Mig or CXCL9), and IFN-inducible $\mathrm{T}$ cell chemoattractant (ITAC or CXCL11), have been shown to exert chemotactic effects on mononuclear cells (both $\mathrm{T}$ cells and monocytes) and possess angiostatic properties, whereas $\mathrm{ELR}^{+} \mathrm{CXC}$ chemokines predominantly influence neutrophil trafficking and promote angiogenesis. ${ }^{(1,2)} \mathrm{ELR}^{-} \mathrm{CXC}$ chemokines are also potent inducers of natural killer (NK) cell recruitment both in vitro and in vivo, and IP-10 and Mig have recently been shown to induce chemotaxis of specific NK T cell subsets. ${ }^{(3-5)}$ The G-protein-coupled receptor CXCR3 serves as the sole receptor for $\mathrm{ELR}^{-} \mathrm{CXC}$ chemokines. CXCR3 is expressed on activated T cells, predominantly of the Th1 phenotype, as well as NK cells, NK T cells, and a subset of circulating memory $\mathrm{CD} 4^{+}$and $\mathrm{CD} 8^{+}{ }^{+}$cells. ${ }^{(6)}$

$\mathrm{ELR}^{-}$CXC chemokines have been closely linked with the generation of Th1-type inflammatory responses. For example, IP-10 is expressed in increased amounts in infections that require a vigorous type 1 immunity, including antimicrobial responses against mouse hepatitis virus and intracellular bacterial pathogens, such as Mycobacterium bovis and Rickettsia conorii. ${ }^{(7-9)}$ IP-10 is also expressed in a wide variety of inflammatory disease states manifest by overzealous type 1 in-

Division of Pulmonary and Critical Care Medicine, University of Michigan Medical Center, Ann Arbor, MI 48109. 
flammation, including atherosclerosis, multiple sclerosis, rheumatoid arthritis, inflammatory bowel disease, sarcoidosis, and allograft rejection. ${ }^{(10-13)}$ Importantly, mice deficient in IP-10 display impaired clearance of mouse hepatitis virus from the brain, which is associated with reduced $\mathrm{CD}^{+}$and $\mathrm{CD} 8^{+} \mathrm{T}$ cell influx and IFN- $\gamma$ production. ${ }^{(14)}$ Moreover, prolonged survival of cardiac allografts is observed in mice that lack CXCR3 or in which IP-10 is neutralized. ${ }^{(13)}$ Conversely, the transient transgenic expression of human IP-10 in the lung during mouse airway allergen sensitization blocked the development of allergic inflammation, as evident by reduction in the numbers of airway eosinophils and Th2 phenotype $\mathrm{CD}^{+}{ }^{+} \mathrm{T}$ cells. ${ }^{(15)}$

Viral vectors continue to be the most efficient means to transfer genes to various organs in vivo, including the lung. We and others have employed recombinant adenoviral vectors delivered intratracheally (i.t.) to effectively transfer genes to the lung airway epithelium..$^{(4,15-17)}$ However, gene therapy using adenoviruses and other viral vectors is often complicated by dosedependent acute inflammatory responses, characterized by the early expression of proinflammatory cytokines and influx of neutrophils, followed by the accumulation of activated $\mathrm{CD} 4^{+}$ $\mathrm{T}$ cells, cytotoxic $\mathrm{CD} 8^{+} \mathrm{T}$ cells, and generation of antiviral antibodies. ${ }^{(18-20)}$ Factors that promote the recruitment and activation of T cells in response to adenoviral vector exposure have been poorly defined. In the current study, we transiently expressed murine IP-10 in the lungs of C57B6 mice using adenoviral gene therapy to test the hypothesis that IP-10 could independently promote type 1 responses in the lung in vivo and to more completely characterize the cellular response to adenoviral vectors when delivered into the lung. Our results indicate that the transient transgenic expression of IP-10 induces early accumulation of neutrophils, NK cells, and NK T cells, followed by increases in the numbers of $\mathrm{CD}^{+}$and $\mathrm{CD}^{+} \mathrm{T}$ cells. Furthermore, the replication-deficient control adenoviral vector also promoted lung inflammatory cell influx, which was mediated, in part, by adenovirus-induced expression of IP-10.

\section{MATERIALS AND METHODS}

\section{Reagents}

Recombinant murine IP-10 and biotinylated antimurine IP-10 and antimurine IFN- $\gamma$ antibodies used in the enzyme-linked immunosorbent assay (ELISA) or intracellular cytokine staining were purchased from R\&D systems (Minneapolis, MN).

\section{Generation of recombinant adenovirus encoding murine IP-10}

The murine IP-10 (MuIP-10) gene was cut by restriction enzymes Agel and Nhel from pBlast MuIP-10 (InvivGen, San Diego, CA), resulting in a 373-bp MuIP-10 fragment. Plasmid pACCMV2 (4769 bp) was obtained from the University of Michigan Vector Core and was digested by XbaI (931) and XmaI (942) to obtain a 4758-bp backbone. We then ligated the MuIP-10 gene and pACCMV2 backbone to get a 5.1-kp recombinant plasmid. A full-length E1, E3-deleted recombinant adenovirus was generated using in situ loxP recombinant between the shuttle vector (linearized with Nhel) and the cAd5deltaE3.LoxP cosmid containing the Ad5 backbone (linearized with Cla1) in the presence of purified Cre recombinant. ${ }^{(21)}$ The resulting recombinant adenoviral DNA was then transfected into HER 911 cells by standard calcium phosphate precipitation methods. Recombinant clones were identified as plaques in soft agar culture and characterized by ELISA to verify the presence of IP-10 prior to further amplification. Large-scale, high-titer adenoviral purification, particle determination (particles $/ \mathrm{ml}$ ), and titer determination (plaque-forming units $[\mathrm{pfu}] / \mathrm{ml}$ ) were performed using the University of Michigan Vector Core modification of established methods. ${ }^{(22)}$ Aliquots of AdcmvmIP10 (Ad IP-10) and Adcmvplpa (Ad CTL) were maintained at $-80^{\circ} \mathrm{C}$ until immediately prior to use.

\section{Mice}

Female specific pathogen-free 6-8-week-old C57BL/6J mice were purchased from Jackson Laboratory (Bar Harbor, ME) and housed in specific pathogen-free conditions within the animal care facility at University of Michigan until the day they were killed.

\section{Intratracheal inoculation of Ad IP-10 or Ad CTL}

Mice were anesthetized by intraperitoneal (i.p) injection of a ketamine/xylazine mixture. The trachea was exposed, and $30 \mu \mathrm{l}$ saline containing $10^{9} \mathrm{pfu}$ of Ad IP-10 or Ad CTL was administered via a sterile 26-gauge needle, and the skin incision was closed via surgical staples.

\section{Total lung leukocyte preparation}

Lungs were removed from euthanized animal, and leukocytes were prepared as previously described. ${ }^{(23)}$ Briefly, lungs were minced with scissors to a fine slurry in $15 \mathrm{ml}$ digestion buffer (RPMI, 10\% fetal bovine serum [FBS], $1 \mathrm{mg} / \mathrm{ml}$ collagenase [Boehringer Mannheim Biochemical, Mannheim, Germany]), $30 \mu \mathrm{g} / \mathrm{ml}$ DNase [Sigma, St. Louis, MO] per lung. Lung slurries were enzymatically digested for $30 \mathrm{~min}$ at $37^{\circ} \mathrm{C}$. Any undigested fragments were further dispersed by drawing the solution up and down through the bore of a 10-ml syringe. The total lung cell suspension was pelleted, resuspended, and spun through a $40 \%$ Percoll gradient to enrich for leukocytes. Cell counts and viability were determined using trypan blue exclusion counting on a hemacytometer. Cytospin slides were prepared and stained with a modified Wright-Giemsa stain.

\section{Multiparameter flow cytometric analyses}

Cells from mice treated with i.t. administration of Ad IP-10 or Ad CTL were isolated from lung digests as described. For analyses of T cell subsets, isolated leukocytes were stained with the following FITC-labeled or PE-labeled antibodies: anti- $\gamma \delta \mathrm{T}$ cell receptor (TCR), anti- $\alpha \beta$-TCR, anti-CD8, anti-CD4, antiDX5, and anti-CD69 (all reagents from PharMingen, San Diego, CA, unless otherwise noted). In addition, cells were stained with anti-CD45-Tricolor (Caltag Laboratories, South San Francisco, CA), allowing for discrimination of leukocytes from nonleukocytes and, thus, eliminating any nonspecific binding of $\mathrm{T}$ cell surface markers on nonleukocytes. T and NK cell subsets were analyzed by first gating on CD $45^{+}$lymphocyte-sized leukocytes, then examined for FL1 and FL2 fluorescence expression. Cells were collected on a FACScan or 
FACScalibur cytometer (Becton Dickinson, San Jose, CA) using CellQuest software (Becton Dickinson). Analyses of data were performed using the CellQuest software package. Percent positive cells indicated in histogram plots represents the percentage of positive cells back-calculated to total leukocytes.

\section{Intracellular cytokine staining}

Cells were obtained from lung digests as previously described. Intracytoplasmic cytokine staining was performed using the Cytofix/Cytoperm Plus kit and the manufacturer's protocol (BD PharMingen, San Diego, CA). Cells were then stimulated with PMA and ionomycin for $3 \mathrm{~h}$ at $37^{\circ} \mathrm{C}$, then stained for surface expression of CD4, CD8, and DX5 (pan-NK cell marker) using FITC-labeled antibody (BD PharMingen). Cells were fixed and permeabilized with Cytofix/Cytoperm solution for $20 \mathrm{~min}$ on ice. After washing, cells were stained for intracytoplasmic IFN- $\gamma$ expression with purified antimurine IFN- $\gamma$ antibodies (BD PharMingen) diluted in Perm/Wash solution for $30 \mathrm{~min}$. Cells were analyzed as previously described.

\section{Isolation and reverse transcription-PCR amplification of whole lung $m R N A$}

Whole lung was harvested, immediately snap-frozen in liquid nitrogen, and stored at $-70^{\circ} \mathrm{C}$; then, reverse transcription (RT)PCR was performed as previously described. ${ }^{(23)}$ Briefly, total cellular RNA from the frozen lungs was isolated, reverse-transcribed into cDNA, and then amplified using specific primers for MuIP-10, with $\beta$-actin serving as a control. The primer had the sequences 5'-ATC-ATC-CCT-GCG-AGC-CTA-TC-3' and 5'-GAA-CTG-ACG-AGC-CTG-AGC-TA-3' for IP-10; 5' -ATGGAT-GAC-GAT-ATC-GCT-C-3' and 5'-GAT-TCC-ATA-CCCAGG-AGG-G-3' for $\beta$-actin. After amplification, the samples (20 $\mu \mathrm{l})$ were separated on a $2 \%$ agarose gel containing $5 \mu \mathrm{l} / 100$ $\mathrm{ml}$ ethidium bromide (Sigma, $10 \mathrm{mg} / \mathrm{ml}$ ), and bands were visualized and photographed using UV transillumination.

\section{Real-time quantitative RT-PCR}

Measurement of gene expression was performed using the ABI Prism 7000 Sequence Detection System (Applied Biosystem, Foster City, CA) as previously described. ${ }^{(24)}$ Briefly, primer and probe for $\beta$-actin and IP-10 were designed using Shortcut to Primer Express software (Applied Biosystems). The primers, placed in different exons, were tested not to amplify genomic DNA. Primers and probe nucleotide sequences for MuIP-10 were as follow: forward primer, 5'-CCA-GTG-AGA-ATG-AGG-GCC-ATA-3'; reverse primer, 5'-CTC-AAC-ACG-TGG-GCA-GGA-T-3'; TaqMan probe, 5'(FAM)-CTT-GAA-ATC-ATC-CCT-GCG-AGC$\mathrm{C}$-(TAMR) $3^{\prime}$. Primers and probe nucleotide sequences for $\mathrm{Mu} \beta$ actin were forward primer, 5'-CCG-TGA-AAA-GAT-GACCCA-GAT-C-3'; reverse primer 5'-CAC-AGC-CTG-GATGGC-TAC-GT-3'; TaqMan probe, 5'-(FAM)-TTT-GAG-ACCTTC-AAC-ACC-CCA-GCC-A-TAMRA-3'. Specific thermal cycling parameters used with the TaqMan One-Step RT-PCR Master Mix Reagents kit included $30 \mathrm{~min}$ at $48^{\circ} \mathrm{C}, 10 \mathrm{~min}$ at $95^{\circ} \mathrm{C}$, and 40 cycles involving denaturation at $95^{\circ} \mathrm{C}$ for $15 \mathrm{sec}$, annealing/extension at $60^{\circ} \mathrm{C}$ for $1 \mathrm{~min}$. Relative quantitation of IP-10 mRNA levels was plotted as fold change compared with untreated control. All experiments were performed in duplicate.

\section{Murine cytokine ELISA}

MuIP-10 was quantitated using a modification of a double ligand method as previously described. ${ }^{(23)}$ Standards were $1 / 2$ $\log$ dilution of murine recombinant cytokine from $1 \mathrm{pg} / \mathrm{ml}$ to $100 \mathrm{ng} / \mathrm{ml}$. This ELISA method consistently detected MuIP-10 concentrations $>50 \mathrm{pg} / \mathrm{ml}$. The ELISA did not cross-react with other cytokines tested.

\section{Statistical analyses}

Statistical significance was determined using the MannWhitney test or unpaired $t$-test. All calculations were performed using Prism 3.0 software program for Windows (GraphPad Software, San Diego, CA).

\section{RESULTS}

\section{Induction of IP-10 MuRNA after i.t. administration of Ad CTL or Ad IP-10}

To assess the efficacy of i.t. delivery of Ad IP-10 on subsequent IP-10 production, C57BL/6J mice were administered either $10^{9}$ pfu control adenovirus (Ad CTL) or recombinant IP-10 containing adenovirus (Ad IP-10). Lungs were harvested at various times thereafter. As shown in Figure 1A, administration of Ad CTL induced early expression of IP-10 mRNA (24 h), with a second peak of IP-10 mRNA expression at 7 days postvector challenge. By comparison, IP-10 mRNA was markedly upregulated within the lung by $24 \mathrm{~h}$ post-Ad IP-10 administration, with declining expression by days 2 and 3. A second peak of IP-10 expression was noted by day 7 post-Ad IP-10 challenge. Additionally, we used real-time RT-PCR to better quantitate IP-10 expression at various times after Ad IP-10 or Ad CTL treatment. As shown in Figure 1B, IP-10 expression was strongly increased in the Ad IP-10-treated mice at day 1 (>6000-fold), with continued expression to day 7. As observed using semiquantitative PCR, we also observed biphasic induction of IP-10 after administration of control virus alone, albeit to a lesser degree than that observed after Ad IP-10 administration.

\section{Induction of IP-10 protein after i.t. administration of Ad CTL and Ad IP-10}

We next assessed the production of IP-10 protein in whole lung after Ad IP-10 or Ad CTL. As shown in Figure 2, administration of Ad IP-10 ( $\left.10^{9} \mathrm{pfu}\right)$ caused a maximal 5-fold increase in IP-10 levels at $24 \mathrm{~h}$ compared with levels in untreated control lung ( $238 \pm 43 \mathrm{pg} / \mathrm{lung}$ ), with a second smaller peak at day 14 post-Ad IP-10 administration. Moreover, the i.t. administration of control adenovirus also induced an early but lesser peak in IP-10 at $24 \mathrm{~h}$ and a modest but significant increase at 14 days posttreatment.

\section{Effect of i.t. Ad CTL or Ad IP-10 on lung leukocyte accumulation}

To determine the effect of vector administration in the presence or absence of transient transgenic expression of IP-10 on pulmonary inflammatory cell influx, numbers of leukocytes were quantitated in lung digests at 2 and 7 days postvector administration. Administration of Ad CTL caused a progressive 
A
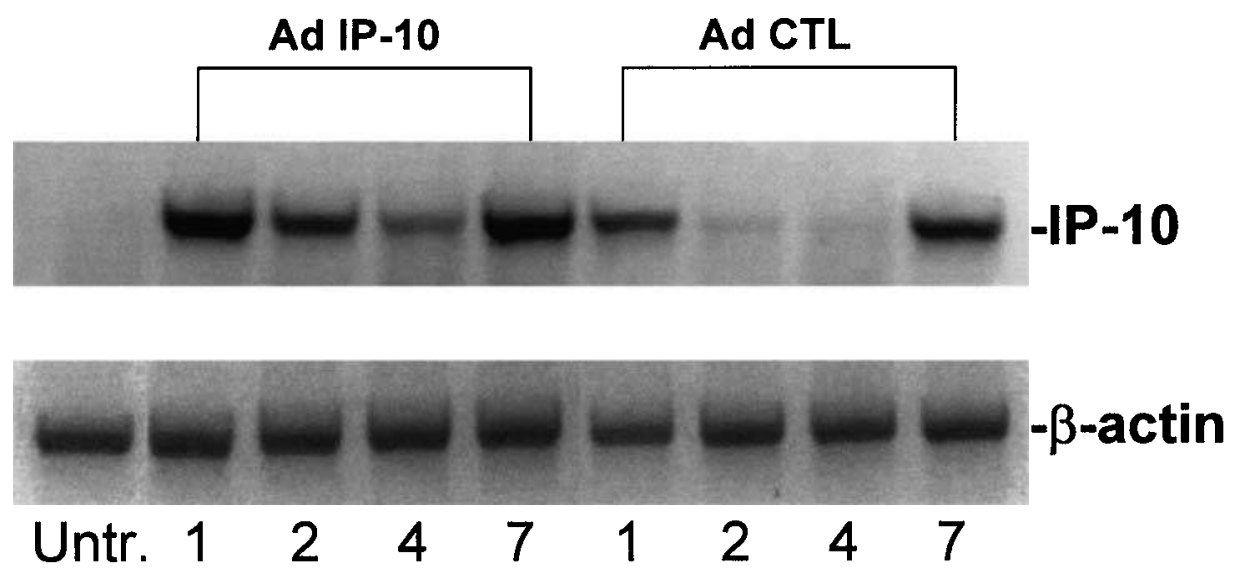

Days Post-Treatment

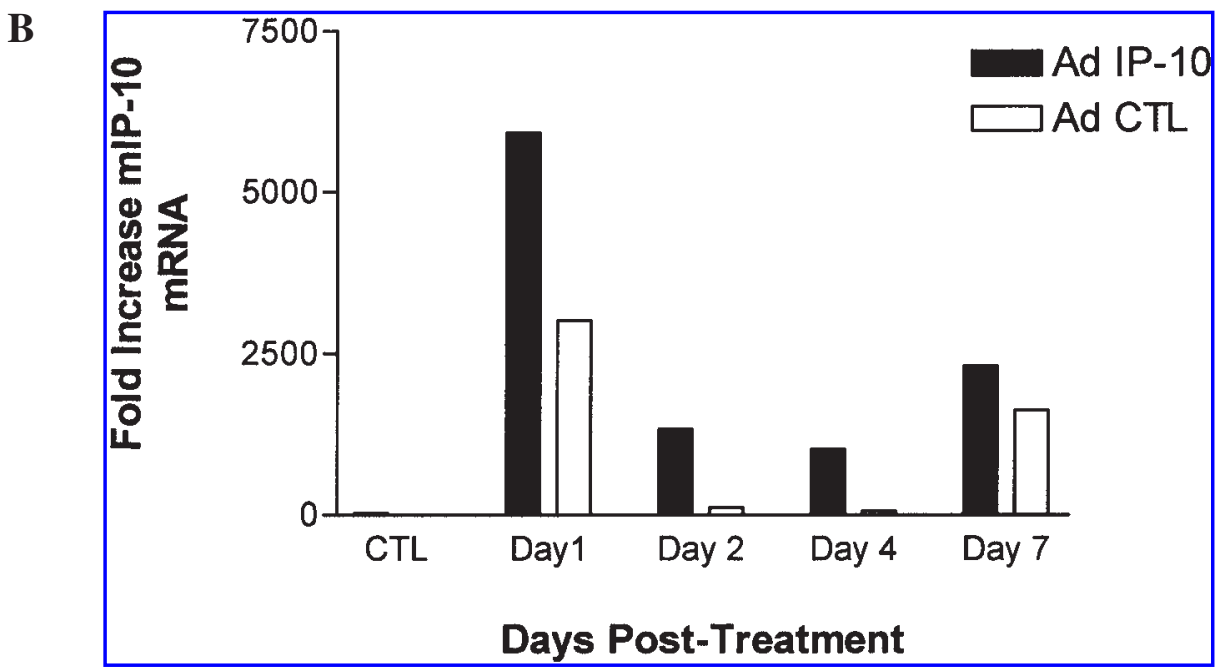

FIG. 1. Effect of i.t. Ad IP-10 or Ad CTL administration on IP-10 mRNA levels in lung homogenates. Animals were treated with $10^{9}$ pfu Ad IP-10 or Ad CTL; then, mRNA levels were assessed in whole lung homogenates at various times thereafter. (A) IP-10 mRNA levels as assessed by RT-PCR. (B) IP-10 mRNA levels as determined by quantitative real-time PCR. For RT-PCR, 30 cycles were performed for IP-10, whereas 25 cycles were performed for $\beta$-actin. For real-time PCR, fold increase represents that over untreated lung. Each lane represents three lungs at each time point combined.

increase in neutrophils over that observed in untreated mice (Fig. 3). Ad CTL also induced the accumulation of mononuclear cells that was significantly greater than that in untreated animals by day 7 postvector administration $(p<0.05)$. In contrast to Ad CTL, a greater increase in lung neutrophils was observed at day 2 after i.t. administration of Ad IP-10, which plateaued by day 7 . Ad IP-10 administration also induced a significant time-dependent increase in lung mononuclear cells, which was maximal at day 7 .

Effect of Ad CTL or Ad IP-10 on accumulation of specific $T$ cell and NK cell subsets

The previous studies indicated that administration of control virus caused an increase in the accumulation of mononuclear cells in the lung, and this effect was significantly augmented in response to transient transgenic expression of MuIP-10. Flow cytometric analysis was performed to determine the specific $\mathrm{T}$, $\mathrm{NK}$, and NK T cell subsets recruited in response to i.t. Ad CTL or Ad IP-10 administration. No changes in T, NK, or NK T cell numbers were noted at day 3 post-Ad CTL administration. However, by day 7, there was a significant increase in the number of $\mathrm{NK}, \mathrm{NK} \mathrm{T}, \mathrm{CD}^{+}$, and $\mathrm{CD} 8^{+} \mathrm{T}$ cells in the lungs of $\mathrm{Ad}$ CTL-treated mice compared with untreated animals $(p<0.05$ for all cells) (Fig. 4). In contrast, overexpression of IP-10 caused a statistically significant increase in NK and NK T cells at 3 days $(p<0.05)$ and a further increase in $\mathrm{CD} 4^{+} \mathrm{T}$ cells and a trend toward increased numbers of $\mathrm{CD}^{+} \mathrm{T}$ cells at 7 days compared with mice receiving Ad CTL.

\section{Effect of Ad CTL or Ad IP-10 on CD69 expression} by lung mononuclear cells

CD69 is a differentiation antigen expressed upon activation by $\mathrm{T}$ cells and NK cells. Given that IP-10 has been demon- 


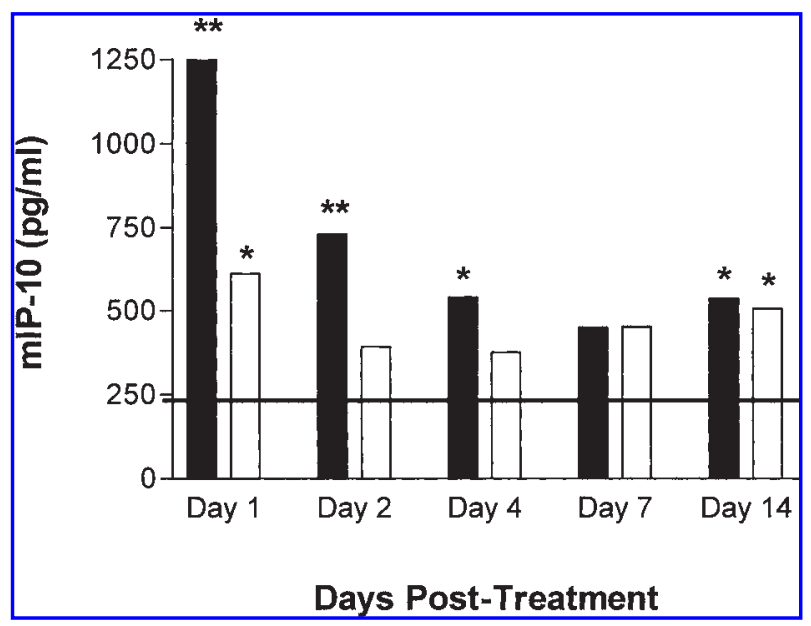

FIG. 2. Effect of i.t. Ad IP-10 or Ad CTL administration on IP-10 protein levels in lung homogenates. Animals were treated with $10^{9}$ pfu Ad IP-10 or Ad CTL. Then, IP-10 levels in whole lung homogenates were assessed at various times thereafter by ELISA. Horizontal line represents mean value of IP-10 levels in control untreated lung. Black bars, Ad IP-10; open bars, Ad CTL. $* p<0.05$ compared with untreated lung; $* * p<0.05$ compared with mice treated with Ad CTL. Experimental $n=$ 4-7 animals per time point.

strated to induce $\mathrm{T}$ cell and NK cell activation in vitro, studies were performed to assess the effect of intrapulmonary IP-10 expression on the accumulation of activated mononuclear cells after Ad CTL or Ad IP-10 administration. The presence of activated cells was defined by the cell surface expression of CD69. As shown in Figure 5, administration of Ad CTL did not cause changes in CD69 expression in T cells (either $\alpha \beta \mathrm{TCR}^{+}$or $\gamma \delta$ $\left.\mathrm{TCR}^{+}\right)$or NK cells $\left(\mathrm{DX}^{+}\right)$at 2 or 3 days. By comparison, i.t. administration of Ad IP-10 caused a substantial increase in activated T cells $\left(\alpha \beta, \gamma \delta \mathrm{TCR}^{+}, \mathrm{CD}^{+} 9^{+}\right)$and activated NK cells $\left(\mathrm{DX}^{+}, \alpha \beta, \gamma \delta \mathrm{TCR}^{-}, \mathrm{CD}^{+} 9^{+}\right)$.

\section{Effect of Ad CTL and Ad IP-10 on cell-associated IFN- $\gamma$ expression}

To determine if either control virus or Ad IP-10 mediated the accumulation of IFN- $\gamma$-producing cells, intracellular cytokine staining for IFN- $\gamma$ was performed. We observed no significant increase in the number of $\alpha \beta \mathrm{TCR}^{+}$, IFN- $\gamma^{+}$cells $(\alpha \beta$ $\mathrm{T}$ cells), $\gamma \delta \mathrm{TCR}^{+}, \mathrm{IFN}-\gamma^{+}$cells $\left(\gamma \delta \mathrm{T}\right.$ cells), or $\mathrm{DX}^{+}$, IFN- $\gamma^{+}$cells (NK plus NK T cells) in Ad CTL-treated mice at day 3 compared with untreated mice (Fig. 6) (data not shown). Likewise, treatment with Ad IP-10 did not alter the number of $\alpha \beta^{+}$, IFN- $\gamma^{+}$T cells (data not shown). However, i.t. administration of Ad IP-10 caused a significant increase in the number of $\gamma \delta^{+}$, IFN$\gamma^{+}$cells and $\mathrm{DX} 5^{+}, \mathrm{IFN}-\gamma^{+}$cells at day 3 posttreatment.

\section{Effect of IP-10 neutralization on adenovirus-mediated accumulation of $N K$ and $T$ cells}

Our previous studies demonstrated significant accumulation of NK and T cells after i.t. administration of the control adenoviral vector, which was associated with the time-dependent expression of IP-10. To determine the contribution of IP-10 to adenovirus-mediated mononuclear cell accumulation, mice were treated with purified rabbit control IgG or polyclonal rabbit antimurine IP-10 antibody ( $5 \mathrm{mg}$ ) every $48 \mathrm{~h}$ starting at the time of i.t. control adenovirus administration. Lungs were harvested at 7 days, and NK and T cell populations were quantitated. The administration of control IgG had no effect on numbers of cells in the lungs of animals receiving saline i.t. (data not shown). As shown in Figure 7, the numbers of $\mathrm{DX} 5^{+}$, $\mathrm{CD}^{+}$, and $\mathrm{CD}^{+}$cells were increased in the lungs of animals

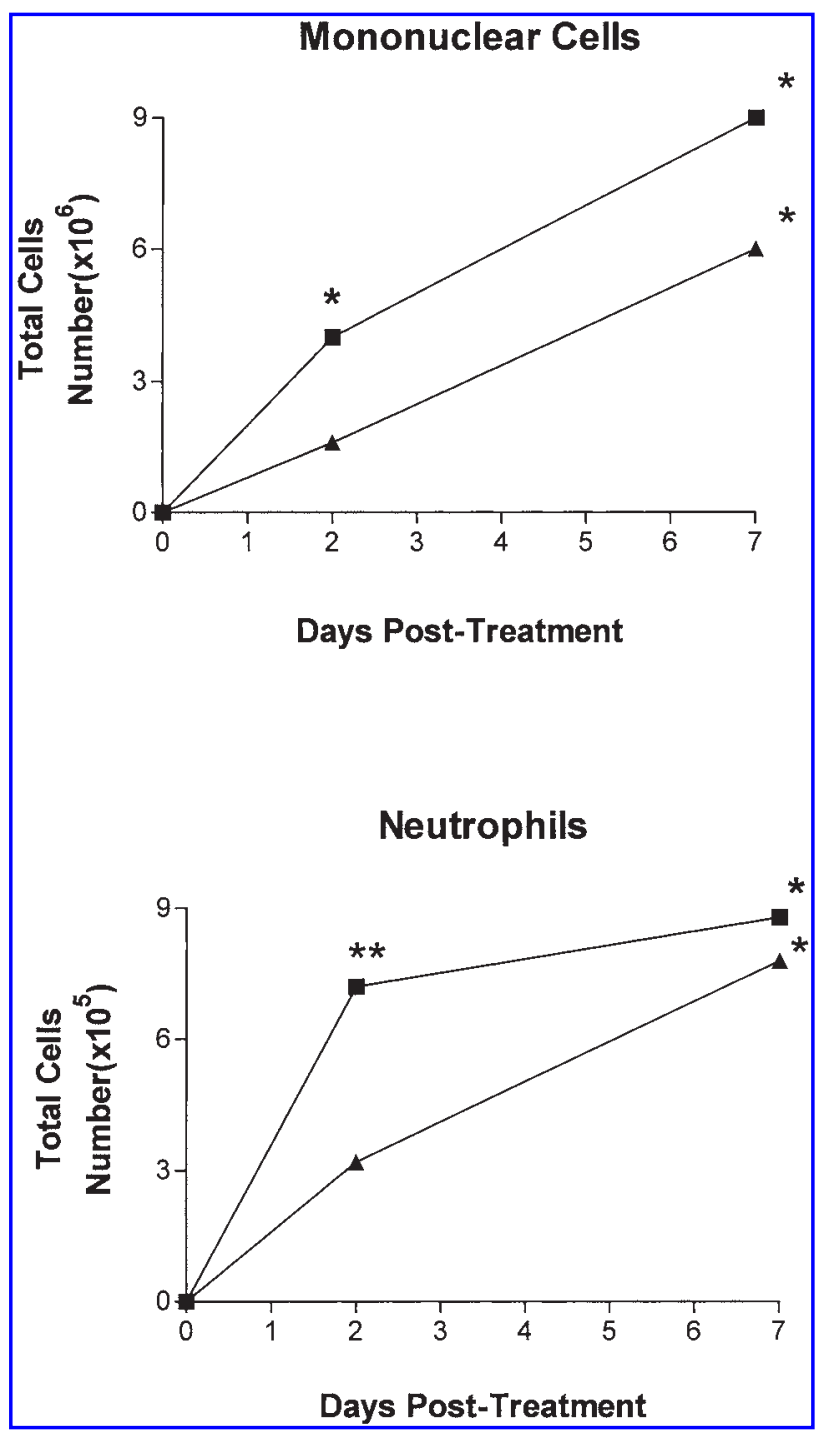

FIG. 3. Effect of i.t. Ad IP-10 or Ad CTL administration on lung mononuclear cell and neutrophil accumulation. Animals were treated with $10^{9}$ pfu Ad IP-10 or Ad CTL. Then, cell counts of isolated whole lung leukocytes were determined at 2 and 7 days postvector administration. Cell numbers shown reflect total cell number found minus total cell number in untreated control lung. Squares, Ad IP-10; triangles, Ad CTL. ${ }^{*} p<0.05$ compared with untreated lung; $* * p<0.05$ compared with mice treated with Ad CTL. Experimental $n=4-7$ animals per time point. 


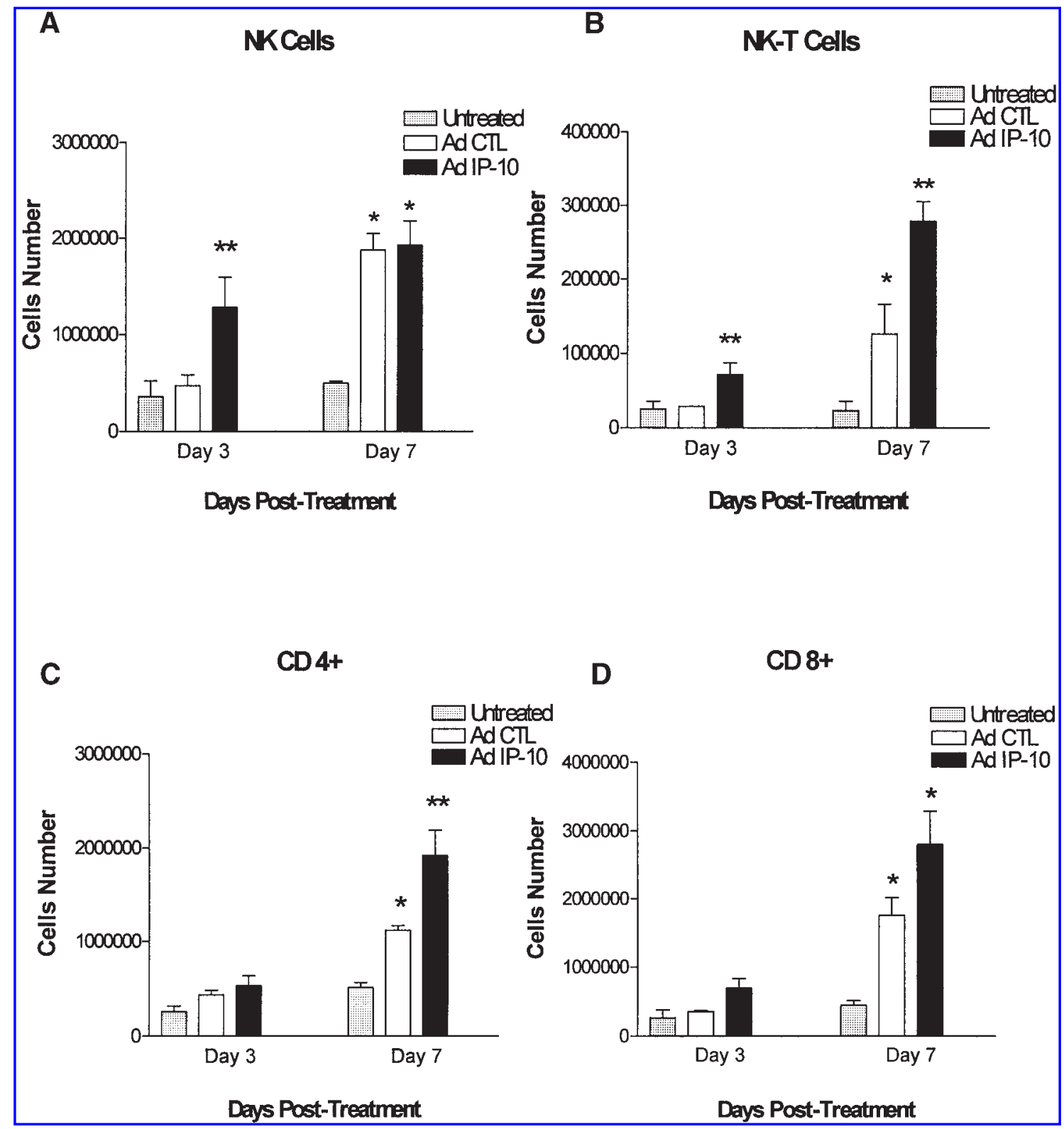

FIG. 4. Effect of i.t. Ad IP-10 or Ad CTL administration on the accumulation of specific mononuclear cell populations. Animals were treated with $10^{9} \mathrm{pfu}$ Ad IP-10 or Ad CTL. Then, numbers of T and NK cell populations in isolated whole lung leukocytes were determined at 3 and 7 days postvector administration by flow cytometry. $* p<0.05$ compared with untreated lung; ** $p<0.05$ compared with mice treated with Ad CTL. Experimental $n=4-7$ animals per time point.

administered control adenovirus $\left(10^{9} \mathrm{pfu}\right)$ i.t. plus control rabbit IgG i.p., compared with saline-challenged animals. Importantly, passive immunization with rabbit antimouse IP-10 antibody caused significant reductions in the number of $\mathrm{DX} 5^{+}$, $\mathrm{CD} 4^{+}$, and especially $\mathrm{CD} 8^{+}$cells $(p<0.05$ for all cell types) in the lung, suggesting that endogenously produced IP-10 mediates the accumulation of these cell populations in response to adenoviral exposure. Furthermore, we observed that neutralization of IP-10 decreased activation of accumulated T cells, as manifest by a $45 \%$ reduction in percentage of $\mathrm{T}$ cells expressing CD69 (data not shown).

\section{DISCUSSION}

Our results indicate that the transient transgenic expression of IP-10 causes site-directed accumulation and activation of selected leukocyte populations in vivo. Most notably, we observed an early influx of NK and NK T cells, followed by a somewhat delayed accumulation of $\mathrm{CD}^{+}{ }^{+}$cells and a trend toward increased $\mathrm{CD}^{+} \mathrm{T}$ cells in response to compartmentalized IP-10 overexpression, compared with animals receiving control adenovirus. Furthermore, intrapulmonary expression of IP-10 caused an increase in the number of activated $\mathrm{T}$ cells and NK 


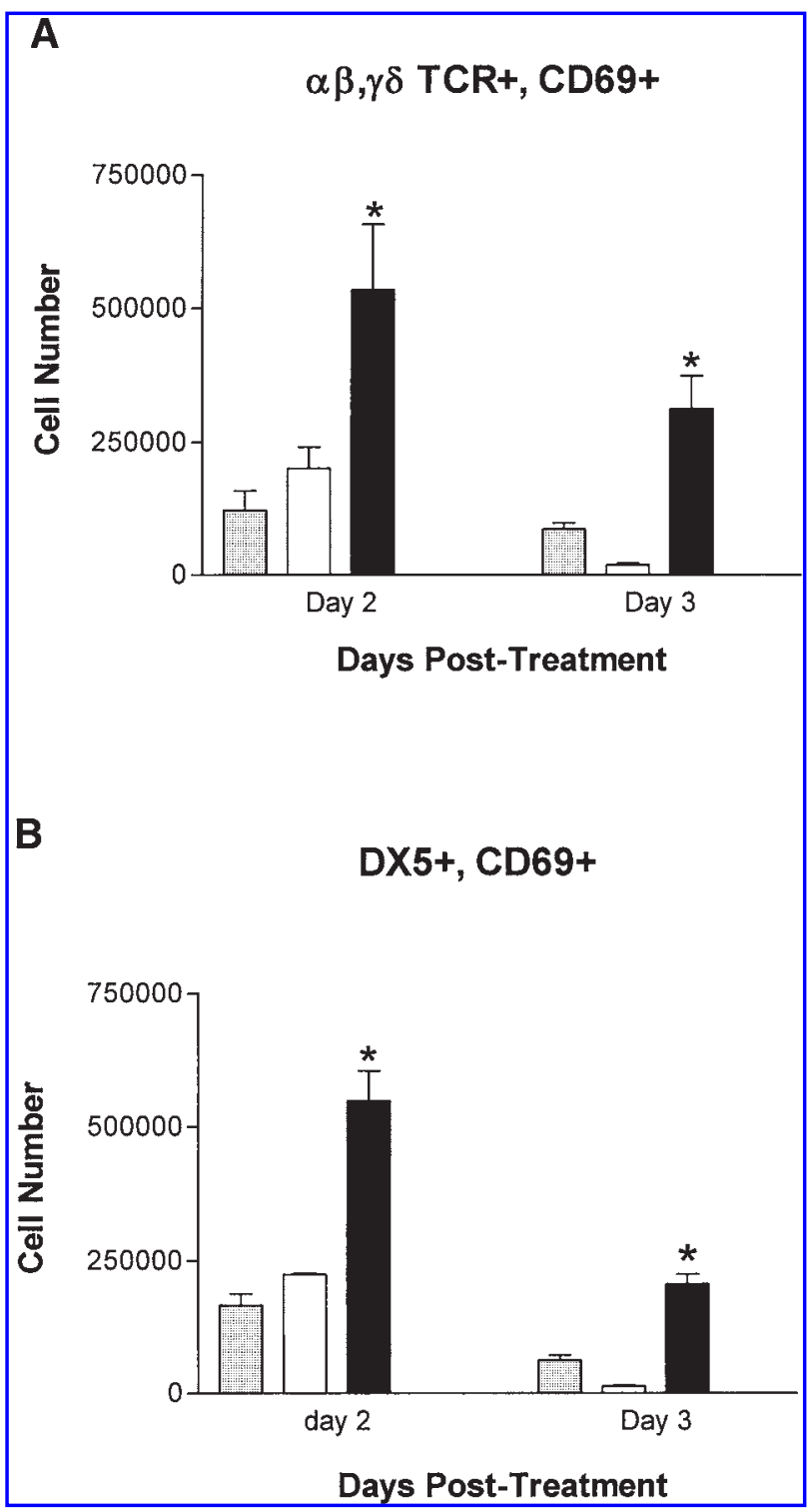

FIG. 5. Effect of i.t. Ad IP-10 or Ad CTL administration on the accumulation of activated T and NK cells. Animals were treated with $10^{9}$ pfu Ad IP-10 or Ad CTL. Numbers of specific cell populations in isolated whole lung leukocytes were determined at 2 and 3 days postvector administration by flow cytometry. Cellular activation was assessed by cell surface expression of the activational marker CD69. T cells were identified by the cell surface expression of either $\alpha \beta$ or $\gamma \delta$ TCR (A), whereas NK cells were identified by the cell surface expression of DX5 (B). Stippled bars, untreated; open bars, AD CTL; black bars, AD IP-10. * $p<0.05$ compared with untreated lung; $* * p<0.05$ compared with mice treated with Ad CTL. Experimental $n=4-6$ animals per time point.

cells, as manifest by CD69 expression and intracellular IFN- $\gamma$ expression. Our results are consistent with observed in vitro effects of IP-10, which has been shown to selectively induce the chemotaxis of NK, NK T, and activated T cells. ${ }^{(2,3,5)}$ Direct in vivo effects of IP-10 on leukocyte recruitment have been less well defined. It has been demonstrated that the intrapulmonary transgenic expression of human IP-10 in rats enhanced $\mathrm{CD} 4^{+}$, $\mathrm{CD}^{+}$, and $\mathrm{NK}$ cell accumulation. ${ }^{(4)} \mathrm{We}$ have confirmed these observations in a murine system and have extended this work to establish NK T cell influx, as well as demonstrating a distinct activated phenotype of mononuclear cells present in the lung. Given the preferential chemotactic effects of IP-10 on subsets of activated $\mathrm{T}$ cells (memory and Th1-phenotype T cells), it is quite plausible that targeted recruitment of these cell populations accounts for the accumulation of CD69 and IFN- $\gamma$-expressing mononuclear cells in the lung. Alternatively, IP-10 may activate mononuclear cells once they have arrived at the

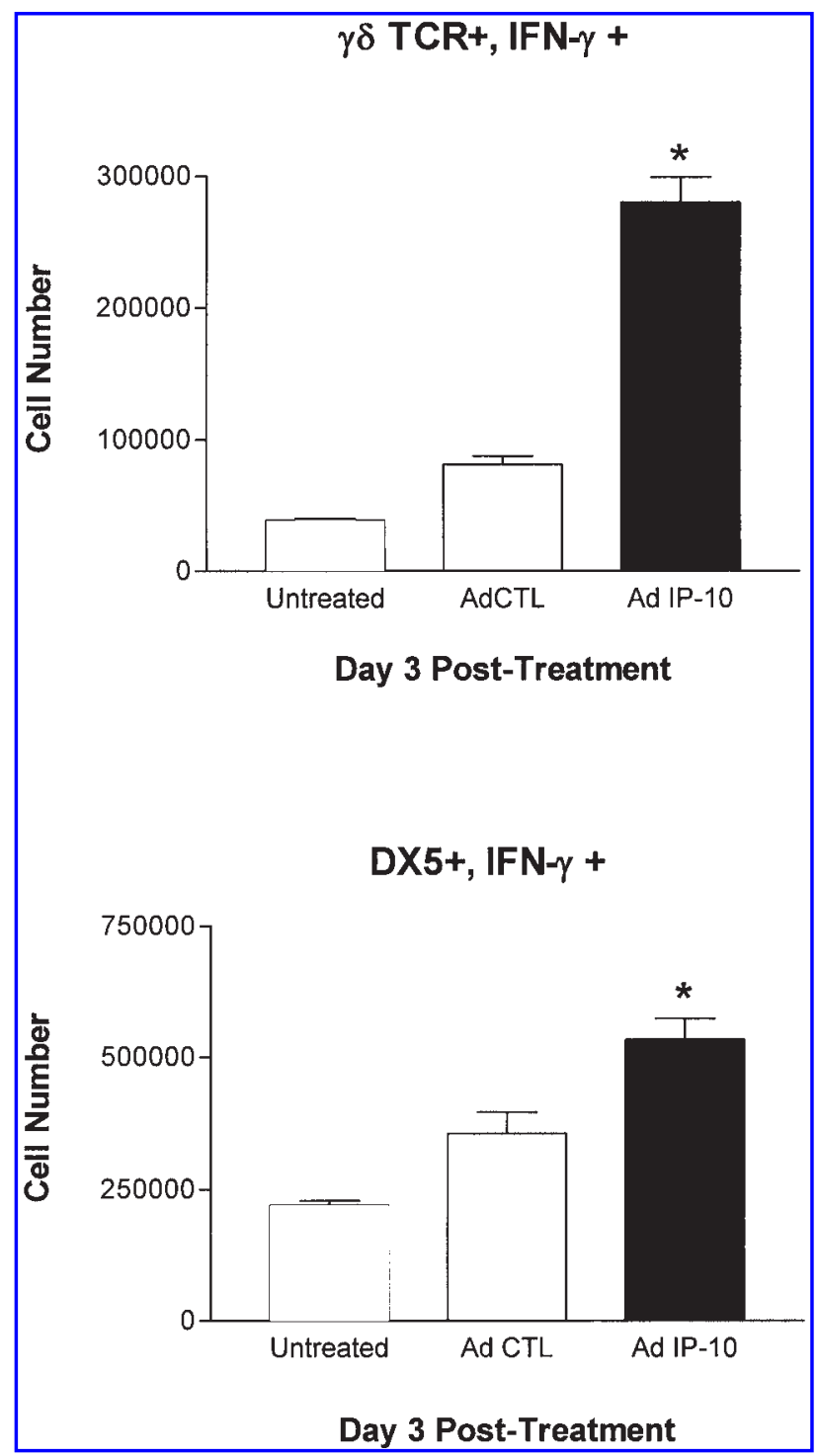

FIG. 6. Effect of i.t. Ad IP-10 or Ad CTL administration on cell-associated IFN- $\gamma$ expression by $\gamma \delta \mathrm{T}$ and NK cells. Animals were treated with $10^{9}$ pfu Ad IP-10 or Ad CTL. Then, numbers of cells expressing cell-associated IFN- $\gamma$ were determined at 3 days postvector administration by flow cytometry. Stippled bars, untreated; open bars, Ad CTL; black bars, Ad IP-10. $* p<0.05$ compared with untreated mice or mice treated with Ad CTL. Experimental $n=4$ animals per time point. 

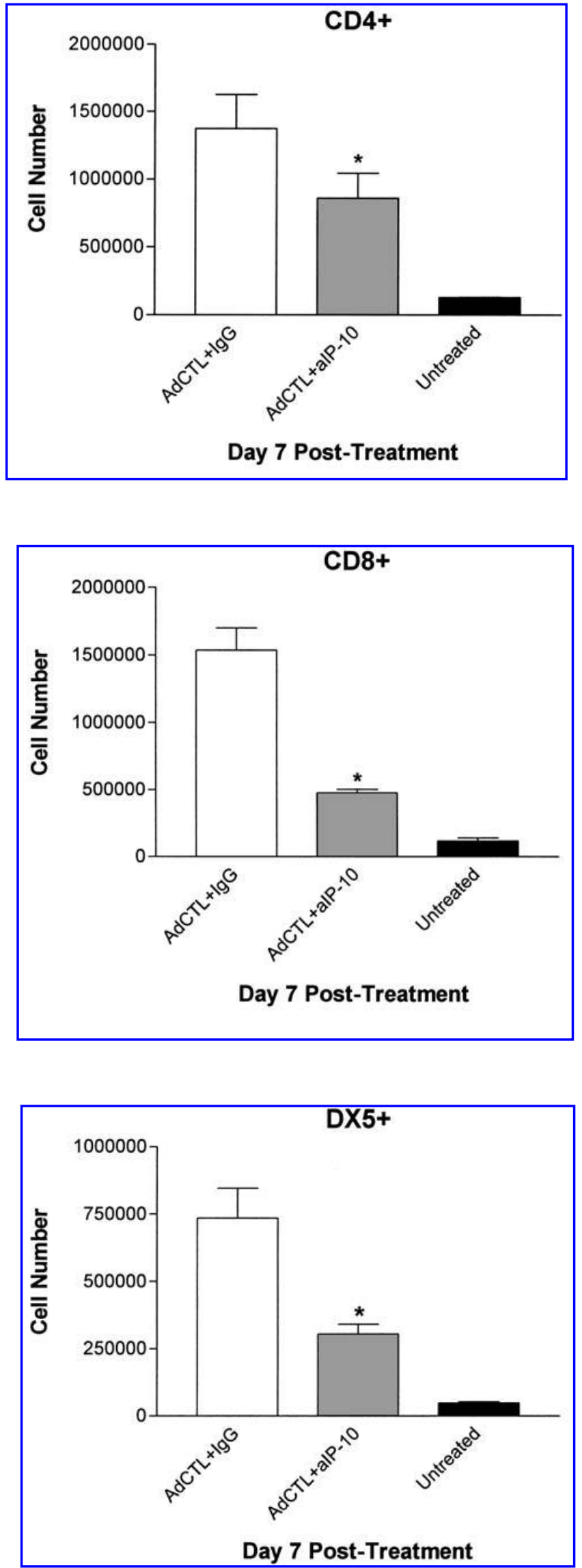

lung. In support of this notion, IP-10 has been shown to directly stimulate NK cell effector function and IFN- $\gamma$ production from T cells..$^{3,25,26)}$ Finally, it is possible the cells recruited to the lung in response to IP-10 produce soluble factors that activate infiltrating cells in a paracrine fashion. Regardless, the compartmentalized expression of IP-10 promotes a microenvironment characterized by the accumulation of cells displaying an activated phenotype.

In addition to increased numbers of $\mathrm{T}$ and NK cells, overexpression of IP-10 was found to enhance the influx of neutrophils over that induced by control adenoviral vector alone. The mechanism accounting for PMN elicitation is unclear, as neutrophils have not previously been shown to express CXCR3 or migrate in response to IP-10 or other ELR-CXC chemokines. However, our results are consistent with those of Palmer et al. ${ }^{(4)}$ who observed increases in BAL neutrophils, maximal at 3 days posttransient transgenic expression of human IP-10 in rats. These investigators found that IP-10-mediated neutrophil influx was abrogated in SCID mice, indicating that activated T cells present within the lung microenvironment were producing factors required for PMN recruitment. However, IP-10 administered subcutaneously in high concentrations has been shown to induce some degree of neutrophilic infiltration even in SCID mice. (27) We observed that neutralization of IP-10 in animals administered control adenovirus caused not only decreases in mononuclear cells but also $>50 \%$ reduction in the number of neutrophils at 7 days postadenoviral challenge (data not shown). Collectively, these data suggest that IP-10 can promote neutrophil migration in vivo, although this effect is likely attributable to cells recruited or cellular products released in response to IP-10.

Our studies also indicate that the human type 5 control adenovirus used was a potent inducer of IP-10 mRNA and protein within the lung. These findings are consistent with those of others, who have reported significant induction of IP-10 in response to adenovirus delivered systemically or compartmentally within the lung. ${ }^{(15,28,29)}$ The induction of chemokines, including IP-10, is partially mediated by capsid proteins and requires binding to cell surface receptors and internalization, resulting in activation of NF- $\kappa \mathrm{B}$ and both the extracellular signal-regulated kinase (ERK) and p38 mitogen-activated protein (MAP) kinase pathways. ${ }^{(30-32)}$ The fact that induction of IP-10 is observed in response to replication-deficient adenovirus indicates that active viral replication is not required for adenovirus-induced cytokine responses. Interestingly, we observed a biphasic pattern of IP-10 expression in response to i.t. adenoviral challenge, with early induction within $24 \mathrm{~h}$, followed by

FIG. 7. Effect of neutralization of IP-10 on accumulation of $\mathrm{CD}^{+}, \mathrm{CD}^{+}$, and $\mathrm{DX} 5^{+}$cells after i.t. administration of $\mathrm{Ad}$ CTL. Animals were administered either purified rabbit control IgG or purified rabbit antimurine IP-10 antibody $(5 \mathrm{mg})$ i.p. concomitant with and every $48 \mathrm{~h}$ after treatment with $10^{9} \mathrm{pfu}$ Ad CTL. Numbers of $\mathrm{CD} 4^{+}, \mathrm{CD} 8^{+}$, and $\mathrm{DX} 5^{+}$cells in lung homogenates were quantitated at 7 days postvector administration by flow cytometry. Open bars, Ad CTL + IgG; stippled bars, Ad CTL + aIP-10; black bars, untreated. a, anti; ${ }^{*} p<$ 0.05 compared with Ad CTL-treated mice receiving control IgG. Experimental $n=6$ animals per time point. 
a later expression of IP-10 message by 7 days postadenoviral administration. This pattern is nearly identical to that observed in liver in response to intravenously administered adenovirus. ${ }^{(27)}$ The early expression of IP-10 may be attributable to the production of this cytokine by resident lung after exposure to the adenovirus itself, whereas the delay in expression of IP-10 may occur as a result of expression from cells recruited in response to IP-10 and other cytokines. Studies are ongoing to evaluate this possibility. In addition to IP-10, we, like others, noted substantial induction of Mig mRNA and protein within the lung in response to i.t. adenovirus, and the expression of Mig also occurred in a bimodel pattern (data not shown).

We noted that blockade of IP-10 in animals challenged with control adenovirus i.t. caused a significant reduction in the influx of $\mathrm{CD}^{+}$and $\mathrm{CD} 8^{+} \mathrm{T}$ cells and NK cells. These findings indicate that IP-10 is a major effector of adenovirus-induced mononuclear cell recruitment. Anti-IP-10 effects were most pronounced for the recruitment of NK cells and $\mathrm{CD}^{+} \mathrm{T}$ cells. Although the contribution of IP-10 to lung inflammation in response to intrapulmonary adenovirus has not previously been demonstrated, it has been reported that neutralization of IP-10 reduced $\mathrm{T}$ cell influx (most notably $\mathrm{CD} 8^{+} \mathrm{T}$ cells) into the liver after i.v. administration of adenovirus. ${ }^{(7)}$ In addition to decreases in the numbers of selected T and NK cell populations, we have observed that neutralization of IP-10 also decreased cell surface expression of CD69 by accumulated T cells (data not shown). Although IP-10 blockade significantly decreased adenovirus-induced mononuclear cell recruitment, this effect was incomplete, suggesting that other factors contribute to pulmonary inflammation in response to adenovirus. This observation is not surprising, as multiple cytokines/chemokines are elaborated after adenoviral exposure, including Mig. In fact, we found that inhibition of Mig also partially mitigated the accumulation of $\mathrm{CD}^{+}{ }^{+}$and $\mathrm{CD} 8^{+} \mathrm{T}$ cells and NK cells, although less impressively than that observed with IP-10 neutralization (data not shown).

In conclusion, our findings indicate that IP-10 is a potent signal for the recruitment and activation of specific $\mathrm{T}$ cell and NK cell populations in vivo. Furthermore, IP-10 contributes to pulmonary inflammation induced by earlier-generation adenoviruses used for in vivo gene transfer. Given the role of IP-10 in mediating in immune responses to adenoviral vectors, future studies are required to determine the effects of IP-10 blockade on the safety and efficacy of gene transfer using adenoviral and possibly other viral vectors.

\section{ACKNOWLEDGMENTS}

We thank Andrew Luster for providing the hamster antimurine Mig antibody. This work was supported by NIH grants PO50 HL60289 and HL57243 (T.J.S.).

\section{REFERENCES}

1. LUSTER, A.D. (1998). Chemokines-chemotactic cytokines that mediate inflammation. N. Engl. J. Med. 338, 436-445.

2. FARBER, J.M. (1997). Mig and IP-10: CXC chemokines that target lymphocytes. J. Leukocyte Biol. 61, 246-257.
3. TAUB, D.D., SAYERS, T.J., CARTER, C.R.D., and ORTALDO, J.R. (1995). $\alpha$ and $\beta$ Chemokines induce NK cell migration and enhanced NK cell cytolytic activity via cellular degradation. J. Immunol. 177, 1809-1814.

4. PALMER, K., EMTAGE, P.C.R., STRIETER, R.M., and GAULDIE, J. (1999). Transient gene transfer of non-ELR chemokines to rodent lung induces mononuclear cell accumulation and activation. J. Interferon Cytokine Res. 19, 1381-1390.

5. JOHNSTON, B., KIM, C.H., SOLER, D., EMOTO, M., and BUTCHER, E.C. (2003). Differential chemokine responses and homing patterns of murine TCR $\alpha \beta$ NKT cell subsets. J. Immunol. 171, 2960-2969.

6. LOETSCHER, M., GERBER, B., LOETSCHER, P., JONES, S.A., PIALI, L., CLARK-LEWIS, I., BAGGIOLINI, M., and MOSER, B. (1996). Chemokine receptor specific for IP-10 and Mig: structure, function and expression in activated T-lymphocytes. J. Exp. Med. 184, 963-969.

7. ARAI, K., LIU, Z.-X., LANE, T., and DENNERT, G. (2002). IP10 and Mig facilitate accumulation of $\mathrm{T}$ cells in the virus-infected liver. Cell. Immunol. 219, 48-56.

8. LANDE, R., GIACOMINI, E., GRASSI, T., REMOLI, M.E., IONA, E., MIETTINEN, M., JULKUNEN, I., and COCCIA E.M. (2003). IFN- $\alpha \beta$ released by Mycobacterium tuberculosis-infected human dendritic cells induces the expression of CXCL10: selective recruitment of NK and activated T cells. J. Immunol. 170, 1174-1182.

9. VALBUENA, G., BRANDFORD, W., and WALKER, D.H. (2003). Expression analysis of the T-cell targeting chemokines CXCL9 and CXCL 10 in mice and humans with endothelial infections caused by Rickettsiae of the spotted fever group. Am. J. Pathol. 163, 1357-1369.

10. BALASHOV, K., ROTTMAN, J., WEINER, H., and HANCOCK, A. (1999). CCR5 ${ }^{+}$and CXCR $3^{+} \mathrm{T}$ cells are increased in multiple sclerosis and their ligands MIP- $1 \alpha$ and IP-10 are expressed in demyelinating brain lesions. Proc. Natl. Acad. Sci. USA 66, 6873-6878

11. PATEL, D., ZACHARIAH, J.P., and WHICHARD, L.P. (2001). CXCR3 and CCR5 ligands in rheumatoid arthritis synovium. $\underline{\text { Clin. }}$ Immunol. 98, 39-46.

12. AGOSTINI, C., CAlAbrese, F., REA, F., FACCO, M., TOSONI, A., LOY, M., BINOTTI, G., VALENTE, M., TRENTIN, L., and SEMENZATO, G. (2001). CXCR3 and its ligand CXCL10 are expressed by inflammatory cells infiltrating lung allografts and mediate chemotaxis of $\mathrm{T}$ cells at sites of rejection. Am. J. Pathol. 158, 1703-1711.

13. ZHAO, D.X.-M., HU, Y., MILlER, G.C., LUSTER, A.D., MITCHELL, R.N., and LIBBY, P. (2002). Differential expression of the IFN- $\gamma$-inducible CXCR3-binding chemokines, IFN-inducible protein 10 , monokine induced by IFN, and IFN-inducible $\mathrm{T}$ cell $\alpha$ chemoattractant in human cardiac allografts: association with cardiac allograft vasculopathy and acute rejection. J. Immunol. 169, 1556-1560.

14. DUFOUR, J.H., DZIEJMAN, M., LIU, M.T., LEUNG, J.H., LANE, T.E., and LUSTER, A.D. (2002). IFN- $\gamma$-inducible protein 10 (IP-10; CXCL10)-deficient mice reveal a role for IP-10 in effector $\mathrm{T}$ cell generation and trafficking. J. Immunol. 168, 3195-3204.

15. WILEY, R.E., PALMER, K., GAJEWSKA, B.U., STAMPFLI, M.R., ALVAREZ, D., COYLE, A.J., GUTIERREZ-RAMOS, J.C., and JORDANA, M. (2001). Expression of the Th1 chemokine IFN$\gamma$-inducible protein 10 in the airway alters mucosal allergic sensitization in mice. J. Immunol. 166, 2750-2759.

16. GREENBERGER, M.J., KUNKEL, S.L., STRIETER, R.M., LUKACS, N.W., BRAMSON, J., GAULDIE, J., GRAHAM, F.L., HITT, M., DANFORTH, J.M., and STANDIFORD, T.J. (1996). IL-12 gene therapy protects mice in lethal Klebsiella pneumonia. J. Immunol. 157, 3006-3012. 
17. STANDIFORD, T.J., WILKOXSKI, J.M., SISSON, T., HATTORI, N., MEHRAD, B., BUCKNELL, K.A., and MOORE, T.A. (1999). Intrapulmonary tumor necrosis factor gene therapy increases bacterial clearance and survival in murine gram-negative pneumonia. Hum. Gene Ther. 10, 899-909.

18. IWAMOTO, H.S., TRAPNELL, C.J., DAUGHERTY, C., and WHITSETT, J.A. (1999). Pulmonary inflammation associated with repeated, prenatal exposure to an E1, E3-deleted adenoviral vector in sheep. Gene Ther. 6, 98-106.

19. THORNE, P.S., McCRAY, P.B. JR., HOWE, T.S., and O'NEILL, M.A. (1999). Early-onset inflammatory responses in vivo to adenoviral vectors in the presence or absence of lipopolysaccharideinduced inflammation. Am. J. Respir. Cell Mol. Biol. 20, $1155-1164$.

20. SHEAN, M.K., BASKIN, G., SULlIVAN, D., SCHURR, J., CAVENDER, D.E., SHELLITO, J.E., SCHWARZENBERGER, P.O., and KOLLS, J.K. (2000). Immunomodulation and adenoviral gene transfer to the lungs of nonhuman primates. Hum. Gene Ther. 11, 1047-1055.

21. AOKI, K., BARKER, C., DANTHINNE, X., IMPERIALE, M.J., and NABLE, G.J. (1999). Efficient generation of recombinant adenoviral vector by Cre-lox recombinantion in vitro. Mol. Med. $\mathbf{5}$, 224-231.

22. HANES, B.D., and GLOVER, D., eds. (1995). DNA Cloning: A Practical Approach. Oxford: Oxford Unversity Press, pp. 285-307.

23. MOORE, T.A., MOORE, B.B., NEWSTEAD, M.W., and STANDIFORD, T.J. (2000). $\gamma \delta$-T cells are critical for survival and early proinflammatory cytokine gene expression during murine Klebsiella pneumonia. J. Immunol. 165, 2643-2650.

24. ZENG, X., MOORE, T.A., NEWSTEAD, M.W., HERNANDEZALCOCEBA, R., TSAI, W.C., and STANDIFORD, T.J. (2003). Intrapulmonary expression of macrophage inflammatory protein $1 \alpha$ (CCL3) induces neutrophil and NK cell accumulation and stimulates innate immunity in murine bacterial pneumonia. Infect. Immun.71, 1306-1315.

25. GAUGUR, V., SIMONS, F.E.R., and HAYGLASS, K.T. (1998). Human IP-10 selectively promotes dominance of polyclonally activated and environmentally antigen-driven IFN- $\gamma$ over IL-4 responses. FASEB J. 12, 705-711.

26. HODGE, D.L., SCHILL, W.B., WANG, J.M., BLANCA, I., REYNOLDS, D.A., ORTALDO, J.R., and YOUNG, H.A. (2002). IL-2 and IL-12 alter NK cell responsiveness in IFN- $\gamma$-inducible protein 10 by down-regulating CXCR3 expression. J. Immunol. 168, 6090-6098.
27. MURUVE, D.A., BARNES, M.J., STILLMAN, I.E., and LIBERMAN, T.A. (1999). Adenoviral gene therapy leads to rapid induction of multiple chemokines and acute neutrophil-dependent hepatic injury in vivo. Hum. Gene Ther. 10, 965-976.

28. TAUB, D.D., LONGO, D.L., and MURPHY, W.J. (1996). Human interferon-inducible protein-10 induces mononuclear cell infiltration in mice and promotes the migration of human $\mathrm{T}$ lymphocytes into the peripheral tissues and human peripheral blood lymphocytes-SCID mice. Blood 87, 1423-1431.

29. ZAISS, A.-K., LIU, Q., BOWEN, G.P., WONG, N.C.W., BARTLETT, J.S., and MURUVE, D.A. (2002). Differential activation of innate immune responses by adenovirus and adeno-associated virus vectors. J. Virol. 76, 4580-4590.

30. LIU, Q., ZAIS, A.K., COLARUSSO, P., PATEL, K., HALJAN, G., WICKHAM, T.J., and MURUVE, D.A. (2003). The role of capsid-endothelial interactions in the innate immune response to adenovirus vectors. Hum. Gene Ther. 14, 627-643.

31. BORGLAND, S.L., BOWEN, G.P., WONG, N.C.W., LIBERMAN, T.A., and MURUVE, D.A. (2000). Adenovirus vector-induced expression of the C-X-C chemokine IP-10 is mediated through capsid-dependent activation of NF- $\kappa$ B. J. Virol. 74, 3941-3947.

32. TIBBLES, L.A., SPURRELL, J.C.L., BOWEN, G.P., LIU, Q., LAM, M., ZAISS, A.K., ROBBINS, S.M., HOLLENBERG, M.D., WICKHAM, T.J., and MURUVE, D.A. (2002). Activation of p38 and ERK signaling during adenovirus vector cell entry lead to expression of the C-X-C chemokine IP-10. J. Virol. 76, 1559-1568.

Address reprint requests or correspondence to: Dr. Theodore J. Standiford Professor, Division of Pulmonary and Critical Care Medicine 6301 MSRB III 1150 W. Medical Center Drive University of Michigan Medical Center Ann Arbor, MI 48109

Tel: (734) 764-4554

Fax: (734) 764-4556

E-mail: tstandif@umich.edu

Received 8 August 2004/Accepted 12 October 2004 
This article has been cited by:

1. Urvashi Bhan, Matthew D Cornicelli, Theodore J Standiford. 2009. Cytokine networks in the infected lung. Expert Review of Respiratory Medicine 2:6, 739-752. [CrossRef]

2. A R Price, M P Limberis, J M Wilson, S L Diamond. 2007. Pulmonary delivery of adenovirus vector formulated with dexamethasone-spermine facilitates homologous vector re-administration. Gene Therapy 14:22, 1594-1604. [CrossRef]

3. Dr. Chilakamarti V. Ramana, Jyothi Chintapalli, Lumei Xu, Christopher Alia, Jing Zhou, Dunja Bruder, Richard I. Enelow . 2006. Lung Epithelial NF- $\varkappa$ B and Stat1 Signaling in Response to CD8+ T Cell Antigen RecognitionLung Epithelial NF- $\varkappa$ B and Stat1 Signaling in Response to CD8+ T Cell Antigen Recognition. Journal of Interferon Cytokine Research 26:5, 318-327. [Abstract] [PDF] [PDF Plus] 